\title{
Protestant ethic: Contributing towards a meaningful workplace
}

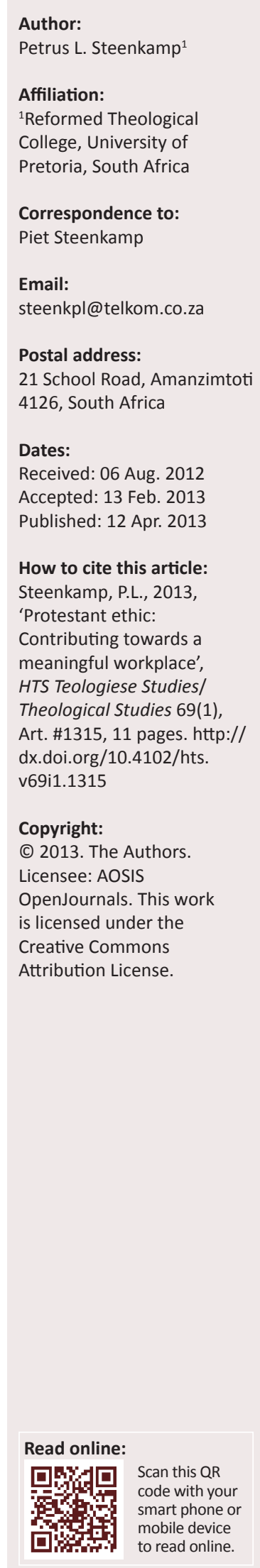

Little did Max Weber know that his essay 'Protestant ethic and the spirit of capitalism', written in 1905 (which was republished in 1920), would survive the times and still be a source for discussion and interpretation during the 21st century. Today as in previous times, work and the workplace poses its challenges. The common thread through history seems to be attempts to enhance the workplace, to better it, to convert it into a place where people could work with a free spirit. Yet, in spite of all the attempts, one failure after the other has been recorded. In a research program that endeavoured to construe the meaningful workplace, Protestant ethic was identified as one possible contributory towards such an ideal. This article explores the contribution of Protestant ethic as a contributory and sets it within the framework of universal individual values pertaining to work and work-specific values. The article also indicates that the Protestant ethic can indeed contribute towards a meaningful experience whilst performing work-related tasks in workspace. The Protestant work ethic is more than a cultural norm that places a positive moral value on doing a good job. Based on a belief that work has intrinsic value for its own sake, it represents a value system that contributes to the experience of meaningfulness whilst performing work.

\section{Introduction}

A previous article established the context and framework of the construct 'a meaningful workplace' and described the two macro-dimensions that contribute towards the meaningful workplace. Against that framework, this article indicates that the Protestant ethic as a concept substantially contributes towards meaningful work experiences and, by means of inference, also serves as a contributory towards the creation of a meaningful workplace.

\section{Background}

The loss of meaning experienced by employees whilst performing work-related activities in the work space has been discussed in an article titled A meaningful workplace: Framework, context and space (Steenkamp \& Basson 2013). It was also stated that the loss of meaning at work inspired the search for the meaningful workplace. In the article referred to above, two macro-constitutive dimensions which are comprised of various constituent categories were identified, each category being comprised of certain factors. During this discussion, reference was made to a 'value cluster' that contributes towards the experience of meaningfulness in the activity of working. By means of an abductive reasoning process, ${ }^{1} \mathrm{I}$ indicated that the value cluster contributes substantially towards meaningfulness at work. Therefore, it also contributes to the construct 'meaningful workplace'. It was also stated that Protestant ethic (PE) $)^{2}$ supports and forms an integral dimension of the value cluster.

The fact that the current discussion focuses on PE does not imply or suggest that other religionspecific values pertaining to work cannot and do not contribute towards the experience of meaning, thereby contributing towards the meaningful workplace ${ }^{3}$. Although the aim of this article is not a comparative study, it would seem possible and even valuable if research were to be undertaken into an ethical system pertaining to economic life (as a class of life activity; economic behaviour is thus a class of behaviour), into a religio-spiritual conceptual approach towards economic life (as a category of economic behaviour), into the comparison between various religio-spiritual faith systems (as types of such a category) and into behavioural markers (as observable phenomena)

1.'Abduction is the process used to infer to the best explanation for an event or phenomenon. It makes its start from the facts, without at the outset having any particular theory in view, though it is motivated by the feeling that a theory is needed to explain the surprising the outset having any particular theory in view, though it is motivated by the feeling that a theory is needed to explain the surprising facts ... from a hypotheses which seems to recommend itself, without at the outset having any particular facts in view, though it feels
the need of facts to support the theory ... it seeks a theory. Induction seeks for facts. In abduction the consideration of the facts the need of facts to support the theory ... it seeks a theory. Induction seeks for facts. In abdu
suggests the hypotheses' (Sebeok \& Umiker-Sebeok as quoted by Balnaves \& Caputi 2001:37).

2.Originally 'coined' by Maximilian Weber (April 21, 1864, Erfurt, Prussia - June 14, 1920, Munich, Germany) in an essay with the title: 'The Protestant ethic and the spirit of capitalism' (1905, and transl. Kalberg in 2002).

3.It is possible to evaluate or describe other religion-related values that impact on the way in which the adherents approach work. This is however not the intent here as it would require a separate discussion and different approach from that followed in this article. 
in an economic system. This is however not pursued here as the focus is limited to the construct Protestant ethic as the spirit of capitalism as proposed by Max Weber. The focus is further on the possible contribution of such an ethic towards a meaningful workplace.

\section{Problem statement and purpose}

There is no doubt that many questions present themselves when a topic such as Protestant ethic is tabled. The questions and uncertainties multiply when the concept Protestant ethic is related to and described as a contributor to the construct 'a meaningful workplace'. Is Protestant ethic (PE), viewed as a value system (by no means the only possible system of this type, i.e. a system founded in religion), important enough to identify it as facilitating meaning in the work environment and thus as a constitutive dimension of the construct 'a meaningful workplace'? Other types of value systems emanating from other religious or faith systems can in their own right also contribute towards meaningful work experiences, and by inference towards a meaningful workplace.

Secondly, is the concept: 'Protestant ethic' meaningful in itself, and is it, within the framework and context of the meaningful workplace in a postmodern setting, still valid to refer to this ethic as such? Thus, can we still refer to the structure of this ethic or value system as 'Protestant'?

Even more fundamental for any reader are the questions: Is an article that discusses PE as a contributor to the experience of meaning a defence thereof, or is it a vindication of Weber's work? Furthermore, does this article represent a particular interpretation of PE? Even more fundamental: Does it propose PE as the only ethical and value system that could contribute to a meaningful workplace?

Questions such as these reach further than purely trying to determine the validity of $\mathrm{PE}$ as a concept or the question whether adherence to such an ethic, specifically applied within the workspace, realistically contribute towards meaningful experiences at work. These questions touch upon the essence, practice and sine qua non of corporate governance. Although it might be interpreted as an individualist perspective, PE acquires a broader scope when viewed against the background of the previous statement pertaining to governance issues. Such an ethic, whether we call it Protestant or anything else, is an unavoidable issue, specifically against the background of fraud, tenderpreneurship, graft and outright theft in the South African context. Without such ethical fibre, the South African society will wither economically, resulting in utmost poverty and the social ills that go with such deterioration.

\section{Structure of the discussion}

The article is structured in the following way. It starts with a discussion on the value cluster which has been referred to earlier. This is followed by a discussion which highlights the $\mathrm{PE}$ as an ethical system that has its roots in Calvinism and more specifically in the theological structure of John
Calvin's thoughts on the doctrine of the elect. Underpinning this discussion, the following elements will be presented: the zeitgeist of the 18th and 19th centuries, Max Weber's perspective in 'The Protestant Ethic and the Spirit of Capitalism', which will include a rendering of Weber's perspective on the characteristics of PE as well as the 16th century background to the publication of Max Weber including the characteristics of PE as Weber saw them. This is followed by an eclectic rendering of research on the concept $\mathrm{PE}$, which will include reference to contemporary research in respect of PE as the spirit of capitalism. In closing, some conclusions will be presented.

\section{Values: Facilitating and supporting meaningful experiences in working}

\section{Personal values}

There is sufficient data to support the statement that values contribute towards meaningful work experience(s). Magdoff (2006), Morse and Weiss 1995 and Sverko, 1999 described what they called the 'Meaning of work model' (based on the project by the Meaning of Work Project Team as referred to in Ros, Schwartz \& Surkiss 1999) ${ }^{4}$ and the values undergirding work. Their research established a link between personal values and work-related values. The meaning of work was conceptualised on multiple levels as indicated below:

- work centrality in people's lives ${ }^{5}$

- work-role identification ${ }^{6}$

- valued working outcomes $^{7}$

- work goals $^{8}$

- $\quad$ societal norms about working. ${ }^{9}$

Values have further been recognised as one of the most important determinants of individual behaviour (Furnham \& Koritsas 1990; Hui 1992; Ros et al. 1999). In this regard, Ros et al. (1999) states that:

A theory of basic human values specifies 10 motivationally distinct types of values, that are postulated as being universally recognised by members of most societies, and that encompass the different values that guide them. (p. 51)

These universally recognised values are imbedded in a typology of four value clusters with which individuals and societies must (and do) cope (Ros et al. 1999). Table 1 indicates the four clusters and the ten basic human or individual values with core definitions. Key towards understanding

4.This 'model' was identified as one of the macro constituent dimensions of the construct 'a meaningful workplace'.

5.This is a measure based on cognitions and affects that reflect the degree of genera importance that work has in the life of an individual at any given time (MOW International Team in Basini \& Buckley 1996-1997).

6.The extent to which an individual defines and identifies working in terms of various roles such as task role, organisational role product or service role and occupational or professional role (Basini \& Buckley 1996-1997).

7.The importance evaluations which are defined to include what the person knows about each of the outcomes and the preference relationship amongst outcomes (Basini \& Buckley 1996-1997)

8.The absolute and relative importance of work-related goals such as job satisfaction work values and incentive preference (Basini \& Buckley 1996-1997).

9.From traditional work ethics, it is possible to derive the orientation of work-related social norms that refer to working as an individual or collective obligation to society, whether such social standards are religiously or otherwise underpinned (Basini \& Buckley 1996-1997) 
TABLE 1: Basic human values in relation to work values.

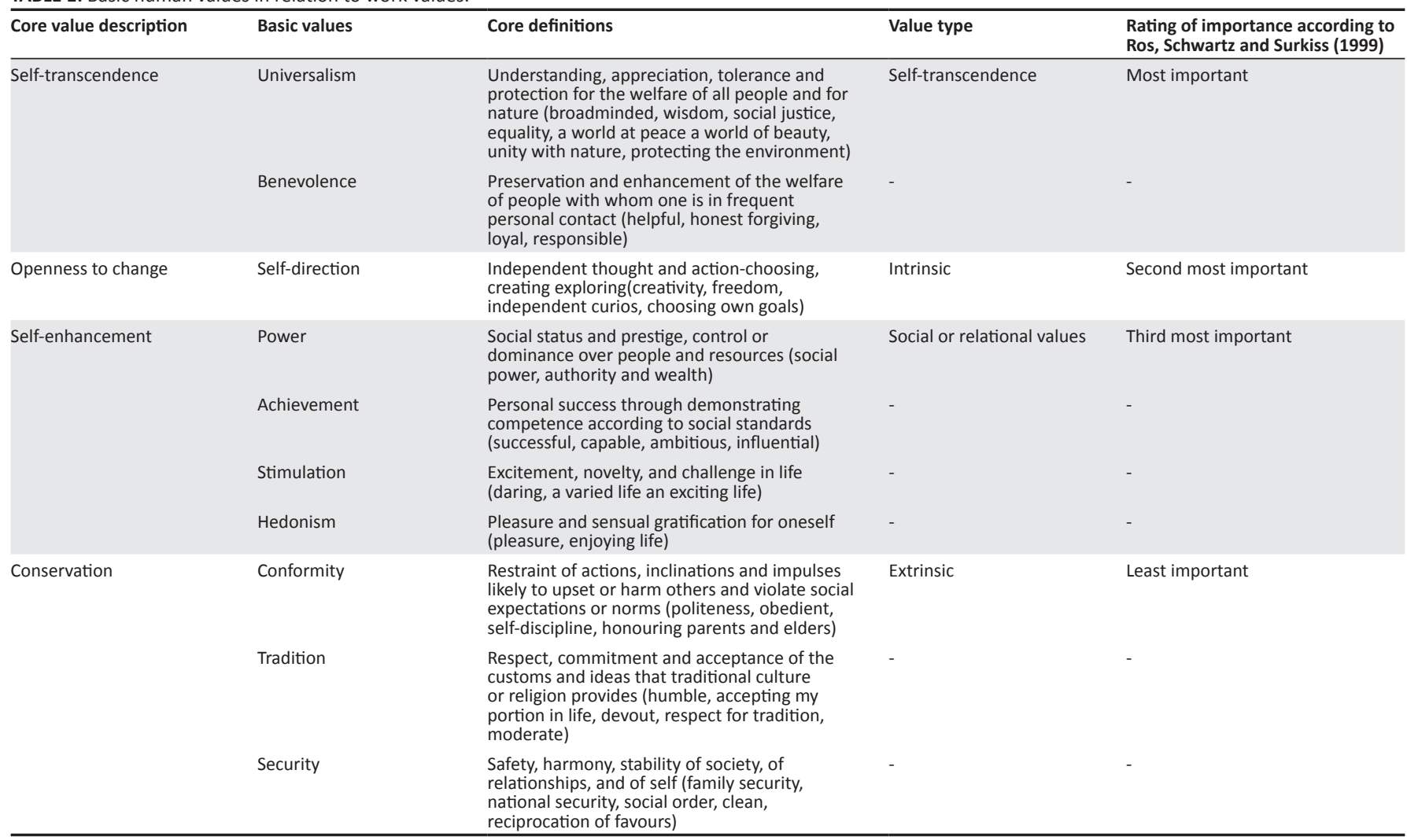

Source: Ros, M., Schwartz, S.H. \& Surkiss, S., 1999, 'Basic individual values, work values and the meaning of work', Applied Psychology: An International Review 48(1), 49-71

Note: The bold broken lines indicate a mutually beneficial and osmotic type of relationship between values and categories, further enhancing the viewpoint that value types are not viewed as Note: The bold broken lines indicate a mutually beneficial and osmotic type of relationship between values and categories, further enhancing the viewpoint that value types are not viewed as
mutually exclusive and further implying a reciprocal transference or influence between the different value categories. It also further confirms the position that these should not be positioned as conflicting but as complementary features.

the different value types and the dynamic interaction is an assumption that there are psychological, practical and social consequences related to these values (Ros et al. 1999).

\section{Work values}

Work values represent specific 'beliefs pertaining to desirable end-states (e.g. high pay) or behaviour (e.g. working with people)' (Ros et al. 1999:54). Work values are defined within a context, and despite a plethora of different labels, researchers all appear to identify the same two or three categories of work values, that is, (1) intrinsic or self-actualisation values, which directly express openness to change, the pursuit of autonomy and interest in growth and creativity at work; (2) extrinsic or security or material values, which compare directly with individual values such as conservation values and include job security and income; (3) social or relational values, which express the pursuit of self-transcendence values where work is seen as a 'vehicle for positive social relations and contribution to society'; and (4) self transcendence, which is a value type that includes such concepts as universalism, (which in this sense refers to the experience of inclusiveness of man based on the notion of self-transcendence, thereby affirming that self-transcendence is a universal human trend), and 'benevolence' (as an indication of a basic disposition to do well through work). Ros et al. (1999) ${ }^{10}$ conclude that the

10.The results of the study by Ros et al. (1999) revealed the following: Prestige work values oppose social-type work values, expressed as self-enhancement versus self transcendence. Extrinsic work values correlated positively with conservation values and negatively wich walues concerning openness to change whereas intrinsic work values correlated negatively with conservation values and positive with values concerning openness to change (Ros et al. 1999:59). I do not share the
mutual exclusiveness of the different value types as postulated by Ros et al. (1999). groups with which they had worked rated self-transcendence values as most important whilst values related to openness to change were rated second. Self-enhancement values were rated third important, and conservation-type values were rated lowest.

We now divert to a discussion of PE before returning to values and the relationship between the $\mathrm{PE}$ as a value system and the link with universal and work-related values.

\section{Protestant ethic: Max Weber's perspective}

\section{The zeitgeist of the 17th and 18th centuries}

The 17th and 18th centuries (in the Western world) can be described as the age of optimism. Europe had emerged from the (so called dark) middle Ages. The new science revealed the universe as a vast but simple and orderly mechanism where linear principles that could be discovered by the human intellect ${ }^{11}$ are at work. As part of such an orderly mechanism, everything is subject to prediction, which implies control and thus accounted for the view of unlimited progress and material and social well-being. The application of science to operational technology, however, dispelled the euphoria and man became sober in the realisation that optimism was a misplaced acceptance of that-which-is-(perceived as)-good (Jones 1975).

11.Consider the work of Isaac Newton in respect of his article: 'Three laws of motion' (Newton 1846:19). 
Certain events, of which the Industrial Revolution (late 18th and early 19th centuries) seems to have had the biggest impact, contributed towards dissolving the optimism. ${ }^{12}$ It brought about urbanisation with its accompanying social and financial hardship, hunger, disease, child labour, et cetera. The industrial revolution, as the dominant force of change in Europe at the time of Max Weber, commenced with the mechanisation of the textile industry and ironmaking techniques, followed by the utilisation of coal as a source of energy and the utilisation of canals as a means to deliver goods over relatively long distances. Improved roads and the railroad contributed to an expansive economic drive. Production capacity was dramatically increased through steam power followed by the use of metal machine tools in the first two decades of the 19th century. This facilitated the increase in production machines and once more boosted production capacity. Western Europe and North America were the ideal breeding grounds for the expansive drive through industry and technology. Measures of control, one of which was financial and monetary, flourished. The flow of capital, monetary exchange and the monetary influence of factory and business owners constituted control over the production capacity of the people. ${ }^{13}$

Around 1850, technological progress gained even more ground with the development of ships with steam engine, followed by the internal-combustion engine and the generation of electric power. These developments provided new opportunities that brought about migration to the cities on an even larger scale.

Within this framework, Protestant ethic gave 'moral sanction to profit making through hard work, organisation, and rational calculation' (Yankelovich 1981:247). This ethic spread throughout Europe and to America through the Protestant sects, in particular, the English Puritans, the French Huguenots and the Swiss and Dutch reformed who subscribed to Calvinist theology, a system that was conducive to productivity and capital growth in its approach towards work and profit making. Beliefs which supported hard work became secularised and were woven into the norms of Western culture (Lipset 1992; Rodgers 1978; Rose 1985; Super 1982). Against this background, Max Weber published his essay, 'Protestant ethic and the spirit of capitalism', in 1905.

\section{Max Weber: The convergence of thought and lifestyle}

It is not the intention to provide a history and background of Maximilian Weber. There are sufficient sources where a biographical description can be accessed. According to Le Roux (2004), Max Weber, throughout his life, was interested in the nature of Western culture, interrogating the social

12.0ther influences that contributed to the disappearance of optimism include the following: the mass dissemination of information through print; the longterm consequences of the Church Reformation formulated certain dogmas that
contributed to the negative experiential effect by people; the French Revolution (1789-1799) - intended to overthrow tyranny, replaced it with formidable tyranny, that is, Napoleon.

13.Tendencies included, for example, the loss of independence and decision making in passing from a subsistence mode of living to the selling of manual labour, the passing on of energy and know-how to the industrialists, the transformation of a society sustained by barter to a society which became dependent on monetary means, et cetera. dynamics that created a different type of cultural pattern to that of Eastern Europe. Apparently Weber made a substantial discovery, which his wife (Le Roux 2004:743) referred to as the 'influence of thoughts and lifestyle'. The Western civilisation and all its forms of existences (i.e. sub-cultures) were established through ideas and style of living. These thoughts were initially formed by the Greeks and supplemented with a particular lifestyle during the Reformation. ${ }^{14} \mathrm{~A}$ theoretical and practical rationalism influenced the West to such an extent that 'reason and ethic' converged. Theory and practical rationalism (a so called double-sided rationalism, see Le Roux 2004) were the breeding ground for the facilitating role of 'the idea' that created the Western world. This type of convergence (if we may call it that) - between theory and rationalism influenced the West to the extent that it eventually caused a cultural pattern distinctly different from Eastern Europe and other cultures. Religious ideas, specifically, gave rise to certain behaviour patterns (according to Weber in Le Roux 2004), which led to a certain type of social and economical behaviour: 'Ideas are always linked to self interest, and only survive for as long as they are linked to real interests, because (ideas) legitimise interests' (Le Roux 2004:744). According to le Roux (2004:744), Weber demonstrated this very clearly in his now famous thesis that the Protestant ethic created the conditions conducive to a certain economic behaviour pattern, that is, capitalism.

\section{The 16th century background to the Protestant ethic according to Weber ${ }^{15}$}

Protestant ethic (as the spirit of capitalism) is based on the doctrines of Christian thinkers, specifically John Calvin, who occupied the religious stage in opposition to the Roman Catholic Church. It is a vast and distinct belief system, underpinned by a systematic, integrated, theological and hermeneutical process that eventually developed into a dialectical theological system. The movement eventually became known and labelled as Protestantism. ${ }^{16}$

The Church Reformation represents a period of religious and political upheaval in Western Europe during the 16th century. Two key figures influenced the development of Western culture and more specifically the approach to work during this period, that is, Martin Luther and John Calvin. ${ }^{17}$ Of the two, John Calvin was the most influential in Max Weber's mental modelling. We will therefore not revert to Martin Luther's thoughts for the purpose of this discussion.

14.Although this 'discovery' was made in 1911 only (Le Roux 2004:477), it is not an error to assume that it was starting to reach fruition seven years earlier.

15.The discussion is at best fragmentary and elective in relation to the purpose of this article.

16.Protestantism, without succumbing to a highly technical theological definition, can be described as a religious movement based on Christian doctrine. As a religious movement, it originated during the 16th century as a result of the protest and resulting controversy and protestation against Roman Catholicism and the Roman Catholic doctrine. It included denying papal authority and the perspective that the pope was the representative of Christ in the world by Martin Luther, John Calvin pope was the representative of Christ in the world by Martin Luther, John Calvin states that the justification of the sinner is by faith alone.

17.The detailed history and theological dissemination of thought during the Reformation by Reformation thinkers can be followed in works dedicated to these themes. This is not the place to go down that avenue - the discussion is only relevant as far as this article goes. 
According to Weber (1905), it was John Calvin (10 July 1509 27 May 1564) who introduced the theological doctrines which formed a significant new attitude toward work. Calvin's concept of predestination was not only revolutionary but in essence was the idea that provided, according to Weber, the impetus for a certain type of economic behaviour, which he described as the spirit of capitalism. Central to Calvinist belief was the elect, those chosen by God to inherit eternal life and who were thus predestined to this end. All other people were damned and nothing could change that since God was unchanging. Whilst it was impossible to know for certain whether a person was one of the elect, one could have a sense of it based on her or his own personal encounters with God.

This inhuman doctrine stemmed a whole generation into a mood of depression and alienation. Who was elected and who was doomed? For Weber, the answer lay in economic activity. According to Calvinism and (later) Puritanism, the outer signs of grace like the sacraments and church membership were ineffective and powerless to 'save' anybody and could not guarantee security in faith. The answer was eventually found in continuous vocational activity (= work). Weber saw these thoughts in practice in the way in which the Puritans and specifically the American sects conducted work and their business. It was a vocation to please God, thereby obeying the calling of God to live and work in his honour. The harder they worked, the more wealth they accumulated and that, in turn, led to positive economic spirals (harder work, more affluence). Thus, this work ethic could be viewed as a self-sustaining motivator to create wealth. This was practical ascetism in a real-world setting and was based on an intrapersonal ascetism and not on an ascetism that led to a separation from the world in some secluded place.

Outwardly, the only evidence of being included in the family of the elect was in the person's daily life and deeds, and success in one's worldly endeavours was a sign of possible inclusion. A person who was indifferent and displayed idleness was most certainly one of the damned, but one who was active, austere and hard-working gave evidence to himself or herself and to others of being one of God's chosen ones (Tilgher 1930). All people are supposed to work because it is the opposite of idleness and simultaneously the fulfilment of one's duty towards God. Work therefore became instrumental in reshaping the world after the will of God. Hording wealth per se was a sin, and therefore, the return on labour had to be invested into new ventures, over and over again.

In addition to and closely aligned to the above, the 'doctrine of calling' (the believers or faithful are called to work towards the glory of God, and thus work itself is virtuous) and an inner-worldly ascetism (saving, investment, amassing capital and reducing costs especially on vices and luxuries) laid the ground rules that, according to Weber, established the spirit of capitalism. Calvinism as a strain or type of Protestantism (category) contained all the elements which fitted into the scheme that Weber perceived, as Bouma (in Furnham 1984:88) argues: 'The central thesis in Weber's work therefore is that PE provided moral justification for the accumulation of wealth.' This conclusion is based on the tendency to trace 'modern'18 capitalism back to its metaphysical roots (Furnham 1984:88).

To understand something of the essence of Protestant work ethic as presented by Weber, it should be borne in mind that Weber followed Benjamin Franklin who offered a number of maxims for everyday conduct such as the following: diligence in work, scrupulous use of time ('do not be idle, for time is money'), 'be frugal in consumption, be prudent, be diligent and ever about your lawful business, cultivate your creditworthiness and put it to good use for credit is money' and the deferment of pleasure (Furnham 1984). These maxims had become part of the popular philosophy of work in the Western world during the 18th and 19th centuries as wealth created the confirmation of being elected (Furnham 1984:88) and were eventually incorporated into the writings of Max Weber (1905). Thus the doctrine of the elect and economic behaviour became linked inseparably. This link could only have survived because of its close relationship with real existential interests - in this case, real economic interests by real people in an economically driven world.

\section{An outdated concept?}

Is PE an outdated concept, or, alternatively, is it still a valid concept to use and refer to specifically in relation to meaningful experience in the workplace? Furnham (1984) answers this question by implication in stating that:

PE is still being drawn upon by journalists, union leadership, philosophers, economists, etc. The irony however is that the validity and accuracy of Weber's specifications of behaviour patterns, goals, and values, emanating from and dictated by Protestant Work Ethic (PWE) i.e. hard work, ascetism, postponement of gratification, frugality, thrift, etc. have stayed intact, in spite of the conflict and sharp debates regarding the validity and accuracy of the historical, sociological and theological hypothesis, which still remain in doubt. Few researchers, however, have denied or challenged Weber's theses, especially in the domains of the validity and accuracy regarding the pattern specifications of behaviour, goals and values as dictated by the PWE. A great deal of research to its measurement and correlates has been conducted by various researchers. (p. 87)

Perhaps reference to a selected body of research will indicate that the concept is still being researched and discussed. At the same time, some empirical evidence points to the validity of the construct although this is not readily accepted without controversy in all cases.

\section{Research on the Protestant work ethic: A psychological perspective (validity and measure as a construct)}

According to Giorgi and Marsh (1990), the construct 'Protestant work ethic' (PWE) was introduced into modern psychology as an assumption in the work of McClelland, who offered a social-psychological explanation for the link between Protestantism and capitalism (see also Furnham 1984). Furnham (1984) assessed the literature in respect of

18.Modern in the sense that Weber used it and not modern in the sense of contemporary. 
TABLE 2a: A summary of research surveyed by Furnham (1984).

\begin{tabular}{|c|c|c|c|}
\hline Author & Date & Field of research & Conclusions from research \\
\hline Nelson & 1973 & History & $\begin{array}{l}\text { Criticism of Weber can be categorised into two categories: (a) those who reject the possibility that } \\
\text { religious and cultural forces can be effective forces in change, and (b) those who deny that religious } \\
\text { outlooks and communities have ever been found to foster the spirit of capitalism }\end{array}$ \\
\hline $\begin{array}{l}\text { Greeley } \\
\text { Lenski }\end{array}$ & $\begin{array}{l}1964 \\
1961\end{array}$ & Sociology & $\begin{array}{l}\text { Concerned whether the PWE beliefs hold true. Bouma (1973) summarises sociological research: (1) } \\
\text { Ascetic Protestantism provides Protestants with greater social mobility and thus higher social status, } \\
\text { (2) Protestant beliefs and norms provide achievement motivation (3) Protestant belief and norms } \\
\text { predispose Protestants to make better use of education }\end{array}$ \\
\hline Bouma & 1973 & Sociology & $\begin{array}{l}\text { Eventually concludes that all the research that he surveyed were of poor quality, thus discrediting the } \\
\text { Weber thesis }\end{array}$ \\
\hline $\begin{array}{l}\text { Ray } \\
\text { Johansson }\end{array}$ & $\begin{array}{l}1982 \\
1947\end{array}$ & Anthropology & $\begin{array}{l}\text { Is the Weber thesis applicable to all countries? (Unfortunately restricted to the English speaking world.) } \\
\text { In Norway the Weberian thesis is supported over and above the Marxist hypothesis }\end{array}$ \\
\hline $\begin{array}{l}\text { Bella } \\
\text { Kennedy }\end{array}$ & $\begin{array}{l}1962 \\
1962\end{array}$ & Anthropology & Found traces in Asian world although concluded that it is a Western importation \\
\hline Furnham and Muhiudeen & 1984 & Anthropology & $\begin{array}{l}\text { Found that a group of Malaysian adults had stronger PWE beliefs than a matched group of British } \\
\text { adults }\end{array}$ \\
\hline Rottenberg & 1975 & Psychopathology & The underlying beliefs of PWE, psychiatry and psychotherapy are inherently contradictory \\
\hline Albee & 1977 & Psychopathology & PWE beliefs lead to psychopathology \\
\hline
\end{tabular}

Source: Steenkamp, P.L., 2012, 'A meaningful workplace: From theory development to applicability', unpublished PhD dissertation, Department of Human Resource Management, University of Pretoria a, Need for achievement.

TABLE 2b: A summary of research surveyed by Furnham (1984): Measurement of Protestant Work Ethic.

\begin{tabular}{|c|c|c|c|}
\hline Author & Date & Field of research & Conclusions from research \\
\hline Blood & 1969 & Psychology & Pro-Protestant Ethic Scale \\
\hline $\begin{array}{l}\text { Wollack } \\
\text { Goodale } \\
\text { Wilting } \\
\text { Smith }\end{array}$ & 1971 & Psychology & Survey of work values \\
\hline $\begin{array}{l}\text { Mirels } \\
\text { Garret }\end{array}$ & 1971 & Psychology & Protestant Work Ethic Scale \\
\hline $\begin{array}{l}\text { Goldstein } \\
\text { Eichorn }\end{array}$ & 1961 & Sociology & $\begin{array}{l}\text { Found that PWE is related to individualism, and ascetism, but not necessarily to productive, systematic, } \\
\text { rational economic behaviour }\end{array}$ \\
\hline
\end{tabular}

Source: Steenkamp, P.L., 2012, 'A meaningful workplace: From theory development to applicability', unpublished PhD dissertation, Department of Human Resource Management, University of Pretoria

the construct PWE and documented many features based on research in psychological literature. Table 2a and Table $2 \mathrm{~b}$ presents a summary of the research based on Furnham (1984:87-104) and includes information on researchers (column 1), date of the research (column 2), results and themes (column 3).

The majority of research has been conducted with a focus on the PWE and paid employment. There is, however, a different angle which Furnham (1984) refers to, that is, the relationship between PWE and unemployment. In a study conducted by Furnham requesting respondents to rate the importance of various social-support programmes, it was found that 'PWE believers were exponents of social responsibility' but responded negatively regarding unemployment and socialbenefit programmes (Furnham 1984:96).

\section{Protestant ethic in other research}

In a study by Giorgi and Marsh (1990), the Protestant work ethic was investigated as a cultural phenomenon. They conclude that, as far as work values are concerned, Western Europeans arrange values regarding work on two axes, which are contrasted by means of extrinsic and intrinsic values. The extrinsic value orientation simply refers to the material benefits of the job whilst the intrinsic rewards or values are concerned with the psychological rewards that the job provides to the individual and society (note the discussion above regarding values). Work is valued as a vehicle to fulfilling personal aspirations and achievement and to satisfy these goals in a socially acceptable environment. ${ }^{19}$ Giorgi and Marsh (1990:507-510) present some answers regarding religious orientation and PWE. Protestants were more likely than Catholics to have high scores on the PWE's ethic factor. The differences displayed in the study did not necessarily reflect beliefs held by individual Protestants or Catholics. Religious culture seemed to be the differentiating factor at both a macro- and micro-level. The European Values Survey indicated that the predominant religious culture may have been the more significant influence. In a comparison between Protestant and Catholic countries, a significant result was obtained. The so-called 'majority protestant countries' (Denmark and Britain) had the greatest number of respondents in the group with the highest work ethic related to the intrinsic value of work. Is there a link between religious conviction and work ethic? Giorgi and Marsh (1990) discovered that:

[a] vocational work ethic was linked with religious denominations in two ways: (a) Protestants endorsed it more that Catholics, [as] it was also more widespread in countries of majority Protestant religion, especially when other factors were held constant. (pp. 514-515)

They (Giorgi \& Marsh 1990:515) also indicate that work was (not always positively) linked with the degree of religious fervour, indicating that it was not those who claimed to be

19.This statement could in a broad and even in a narrow sense of the word be interpreted as a condition for a meaningful workplace. Work as such, in terms of the in reted as a condition for a meaningul wo a socilly acceptable in terms of whe in within which work is done and where the organisation benefit the individual and society offers at least one conceptual base for a meaningful workplace. It is an empowering environment within which personal aspirations can be fulfilled. 
religious who endorsed the work ethic the most but those who claimed to be atheists. To eliminate the influence of variables such as religious denomination and the religion of their country, Giorgi and Marsh (1990) implemented certain controls in their research. Yet in spite of control mechanisms in their research, research participants who indicated their religious orientation as atheist nevertheless reported a positive view of work. Similarly, the Protestant cultural link did not disappear when the strength for religious fervour was controlled. In addition, Giorgi and Marsh also conclude that educational influence and differences indicate that people who had been educated for longer periods of time tended to reflect higher work ethics and values. Their study confirms the validity of the Protestant ethic as a living value system related to the experience of meaningful work.

Can the Protestant ethic be measured? Are there demographic determinants that somehow play a role in PWE beliefs? According to Beit-Hallahmi (1979), PWE scores are closely related to religious self-identification. According to the study, Catholics and Protestants had a higher PWE score than people with other religious identification, that is, Jews and agnostics. As far as the relationship with political selfidentification is concerned, conservatives projected a higher PWE score than what Beit-Hallahmi (1979:226) refers to as 'leftists'. In conclusion, Beit-Hallahmi (1995) indicates that the results may be interpreted as indicating that PWE as an ethical system should not be equated to motivation or achievement. PE can however more adequately be viewed as an approach towards work. It should be regarded as an orientation towards the place and role of work in one's life and society, which to a great extent is related to social background variables. However, at the same time, it reverberates with the studies that have been conducted on personal and work values.

Williams and Sandler (1995) studied the differences between a group of American managers (subscribing to the PWE) and a selected group of Singaporean managers (subscribing to Confucian ethic - CE). They state that the managers that adhere to a PWE were more aligned towards commitment whilst managers subscribing to a Confucian ethic were more committed to satisfaction with work. The latter can be defined as the measure of pleasure and a positive emotional state that an individual experiences whilst performing a job. This measure of joy or pleasure is not limited to isolated cultures but encompasses global worker satisfaction with specific satisfaction dimensions, for example, satisfaction with pay, with the working environment and circumstances, supervision (and management practice), advancement and promotional opportunities, co-workers (social dimension of interaction in the workplace) and organisational practices (Griffin \& Bateman 1986:158; Locke 1976:1300).

Why have Asian countries experienced capital growth as they have? Is it because of the so-called Confucian ethic that values intra- and interpersonal harmony, hierarchy, family integrity and kinship affiliation as well as individual responsibility, thus a more emotional or spiritual orientation
(Hui 1992)? In contrast, commitment, as measured by a scale developed by Porter and others (Williams \& Sandler 1995), measures an attitudinal posture. It captures and reflects the '... relative strength of an individual's identification with and involvement in an organization' according to Mowday, Porter and Steers in Williams and Sandler (1995).

The trend towards commitment in managers subscribing to a PWE reflects identification with and involvement in an organisational setting possibly as a result of the tendency of Protestant ethics to accentuate individualism. The individual thus bases his or her choice on certain considerations, supported by certain values. Therefore, his or her choice cannot be abandoned without substantive reasons. Managers thus feel morally obliged to their personal choice, committed to and responsible for their personal behaviour or actions, and they reflect these in observable work behaviour. ${ }^{20}$

Weber could not have foreseen the discussion of his theses in the 21st century. Space however prevents a detailed discussion of the debate that is still continuing as a result of the Weber theses. Such an overview would indeed be informative and insightful but is passed by in this discussion. Two authors, who evaluated the relevance of the Weber thesis positively, albeit in a modernised form based on inferences drawn from the initial theses, are quoted. Conclusions, or rather certain implications, regarding the application of the Protestant ethic in respect of financial and, more broadly, economic governance, have also been pointed out by researchers in the 21st century.

Etzrodt (2008:49) argues that the PE, as proposed by Weber, cannot be falsified when tested against what he refers to as 'modern capitalism', the founder of which, Adam Smith, was himself a neo-Calvinist. From this perspective, PE as described by Weber remains intact although there might be various strains of critique.

Dahrendorf (2010:11) states that the crisis (global-financial or economic crisis) of 2008 is a clear indication that the 'Puritan culture of hard work and savings has been replaced by consumerism and easy credit' and poses the question whether responsible capitalism, based on the Protestant ethic, should not replace the current trend. Dahrendorf (2010) explains the financial crisis as a result of the transformation of the mentality underlying the behaviour of industrialists, bankers and investors. This mentality caused them to move away from 'savings capitalism' to a 'capitalism of easy credit'. This movement contradicts Weber's principle of deferring immediate consumption in favour of a repeated investment or saving. The fundamental underlying problem for Dahrendorf is that the time perspective of capitalism has shortened and that a new orientation to time is required. This new perspective is one that is inferred from the Weberian perspective on saving and the recirculation of capital - thus

20.This does however not exclude the collective dimension as indicated earlier Individuals in the workplace are not islands in and of themselves. There is always a communal dimension or what can be referred to as workplace community. Within communal dimension or what can be referred to as workplace community. Within
such a context, the interests of the group and eventually the organisation is at stake. 
a long-term perspective. The solution for Dahrendorf is not necessarily a literal return to Protestant ethic as per Weber but, in an inferred sense, the transformation of the time frame within which the economy in capitalist systems is managed and governed. There is after all not any afterlife fantasy in the postmodern world of economic endeavour. Thus, the belief in the afterlife as applied to economic endeavour in our times does not have any holding power and neither does it have any resonance or force. What could happen is a revitalisation of old virtues, which is deemed possible and desirable (Dahrendorf 2010). Bell's paradox of capitalism as quoted by Dahrendorf (2010) is as follows:

the driving force of modern capitalism lies in preferences which no longer strengthen the methods of capitalism. Work, orderliness, service duty remain requirements necessary for prosperity, while at the same time prosperity also denotes consumption, enjoyment, desire and relaxation. People work hard in order to make things which strictly speaking are superfluous ... (p. 22)

In spite of this tendency, the application of PE requires a realistic orientation, based on realistic timelines in order to prevent the consumption mentality, or rather to defer consumption for the sake of affordability.

\section{Alignment: Protestant ethic and work value types}

It is now an opportune moment to return to the discussion on establishing a link between values and PE as a value system as far as meaningful work experiences are concerned.

\section{The mental model of Protestant ethic}

Protestant (work) ethic represents a certain mental model or approach towards work, which in its own right adds value to the experience of meaningfulness at work..$^{21}$ The following discussion focuses on ethics in respect of work against the background of the chosen religio-spiritual system. This discussion will merely focus on the values underpinning the PWE in as far as these contribute to the meaning of work.

Prior to embarking on a comparison between the core values emanating from the Protestant ethic and other work-value types, it is necessary to provide a list, or rather a structure, of the core values of this ethic.

\section{Core values related to Protestant Work Ethic}

Subscribers to the PE differentiate between extrinsic and intrinsic needs and values and place a higher premium on intrinsic values. The assessment of the PWE amongst respondents in different studies furthermore identified the following:

21. However, this does not imply that other religio-spiritual systems do not add value in terms of the experience of meaningful work. The discussion here is an analogy to the value that relio-spirtual systems can add to the experience of meaning to the value that religio-spiritual systems can add to the experience of meaning of people at work. It is thus acknowledged that systems such as Judaism, Islam and Buddhism (and others) could argue that adherents to these also experience meaning whilst working, based on the particular underlying values. This study does not intend, nor is it the scope thereof, to compare the contribution towards the experience of meaning whilst working of the different religio-spiritual systems.
- Hard work as such is viewed as a moral value. This is closely linked with what Weber referred to as the doctrine of calling and the doctrine of predestination. The external signs of being one of the elect are in the measure of success achieved in work, according to Weber.

- Work represents the fulfilment of earthly duties and is viewed as a calling.

- The $\mathrm{P}(\mathrm{W}) \mathrm{E}$ accentuates individualism as a value that is imbedded in a theological system that is referred to as Protestant or more specifically, Calvinism. At the same time, the individual within this scheme of values is also required to live in harmony with the internal (work community) as well as the external (social) community. In purely secular terms, this can be referred to as the abolishment of individual selfishness and transcending the boundaries of the self for the benefit of the other. Protestantism, or rather the underlying ethical and value system, underlines personal responsibility in the intrapersonal as well as the interpersonal (social) domains of life and lived experience, and observable behaviour and work provides the framework for both the areas of responsibility.

- It represents a within-the-world, rational and practical ascetism without falling into the trap of Catholicism's separation from worldly events. In the sense that is used by Weber, it refers to a practical devotional lifestyle that is open to the world and its realities.

- It is tradition bound without ignoring the dynamics of change and adaptation in changing circumstances.

Having stated the above, we can now turn to the alignment between PE, work value types and individual core values (Table 3).

Although Table 3 provides an oversimplified perspective regarding the alignment and overlap between PE and workvalue types, it is nevertheless indicative of the possibilities contained in the comparison.

- Reading across the rows, work-value type can be related to individual core values and the relevant description which, in turn, can then be related to the tenets of the Protestant ethic that can be back-fitted or associated with work values.

- A comparison as in the above table not only indicates the measure of correspondence between the Protestant (work) ethic and individual and core work-value types but also demonstrates the measure of flexibility of the Protestant ethic. This is demonstrated by the perspective that a single PWE identifier can be matched with different work-value types. This is extremely dynamic, bearing in mind the measure of flexibility which confirms the adaptability of Calvinism as foundation for this ethic

- The measure of overlap and flexibility between PE and the core work-value types creates the space to relate such ethical or value considerations as the accumulation of wealth, frugality, and reinvestment of return on investment, deferred consumption', et cetera as a type of capitalism or macroeconomic management and governance system, including financial management 
TABLE 3: Alignment between the Protestant ethic and work value types.

\begin{tabular}{|c|c|c|c|}
\hline \multirow[t]{2}{*}{ Work value type } & \multicolumn{2}{|r|}{ Core individual value clusters } & \multirow[t]{2}{*}{ Core PWE Values } \\
\hline & Basic values & Core definitions & \\
\hline \multirow[t]{3}{*}{ Self-enhancement } & Power & $\begin{array}{l}\text { Social status and prestige, control or dominance over } \\
\text { people and resources (social power, authority and wealth) }\end{array}$ & $\begin{array}{l}\text { Accumulating wealth, but deferring consumerist } \\
\text { behaviour }\end{array}$ \\
\hline & Achievement & $\begin{array}{l}\text { Personal success through demonstrating competence } \\
\text { according to social standards (successful, capable, } \\
\text { ambitious, influential) }\end{array}$ & $\begin{array}{l}\text { Hard work as a moral value and vocation; } \\
\text { Individualism }\end{array}$ \\
\hline & Hedonism & $\begin{array}{l}\text { Pleasure and sensual gratification for oneself (pleasure, } \\
\text { enjoying life) }\end{array}$ & $\begin{array}{l}\text { Enjoyment of the fruits of labour but refrain from } \\
\text { squandering }\end{array}$ \\
\hline \multirow[t]{2}{*}{ Self-transcendence } & Universalism & $\begin{array}{l}\text { Understanding, appreciation, tolerance and protection for } \\
\text { the welfare of all people and for nature (broadminded, } \\
\text { wisdom, social justice, equality, a world at peace a world } \\
\text { of beauty, unity with nature, protecting the environment) }\end{array}$ & $\begin{array}{l}\text { Individual and social responsibility in both the } \\
\text { intra- and interpersonal domains; Responsibility } \\
\text { for the environment; Social equality; Peace }\end{array}$ \\
\hline & Benevolence & $\begin{array}{l}\text { Preservation and enhancement of the welfare of people } \\
\text { with whom one is in frequent personal contact (helpful, } \\
\text { honest forgiving, loyal, responsible) }\end{array}$ & $\begin{array}{l}\text { Social responsibility; Intra- and interpersonal } \\
\text { harmony in the work place }\end{array}$ \\
\hline \multirow[t]{3}{*}{ Conservation } & Tradition & $\begin{array}{l}\text { Respect, commitment and acceptance of the customs and } \\
\text { ideas that traditional culture or religion provides (humble, } \\
\text { accepting my portion in life, devout, respect for tradition, } \\
\text { moderate) }\end{array}$ & $\begin{array}{l}\text { Tradition bound without ignoring the dynamics } \\
\text { of change; Conserving the ethic in spite of the } \\
\text { dynamic of change }\end{array}$ \\
\hline & Conformity & $\begin{array}{l}\text { Restraint of actions, inclinations and impulses likely to } \\
\text { upset or harm others and violate social expectations } \\
\text { or norms (politeness, obedient, self-discipline, honoring } \\
\text { parents and elders) }\end{array}$ & Postponement of satisfaction; Thrift; Frugality \\
\hline & Security & $\begin{array}{l}\text { Safety, harmony, stability of society, of relationships, and } \\
\text { of self (family security, national security, social order, } \\
\text { clean, reciprocation of favours) }\end{array}$ & Social responsibility \\
\hline \multirow[t]{2}{*}{ Openness to change } & Stimulation & $\begin{array}{l}\text { Excitement, novelty, and challenge in life (daring, a varied } \\
\text { life an exciting life) }\end{array}$ & $\begin{array}{l}\text { Does not reject life and the dynamics of changing } \\
\text { circumstances and is open to life's challenges; } \\
\text { Rational and practical (within-worldly) ascetism }\end{array}$ \\
\hline & Self-direction & $\begin{array}{l}\text { Independent thought and action-choosing, creating } \\
\text { exploring(creativity, freedom, independent curios, } \\
\text { choosing own goals) }\end{array}$ & $\begin{array}{l}\text { Individualism and striving towards achievement } \\
\text { and the accumulation of wealth and the expansion } \\
\text { of economic endeavour; Rational and practical } \\
\text { ascetism }\end{array}$ \\
\hline
\end{tabular}

Source: Steenkamp, P.L., 2012, 'A meaningful workplace: From theory development to applicability', unpublished PhD dissertation, Department of Human Resource Management, University of Pretoria

PWE, Protestant Work Ethic.

principles, that differs from outright consumerism. Following Dahrendorf (2010), a more fitting description could be 'responsible capitalism' thus retaining the structure and the content of PE whilst not necessarily retaining the descriptor 'Protestant'.

- PE does not only affect the attitude of the individual towards work but simultaneously poses a challenge in respect of the management of people within organisational settings, as well as issues that relate to organisational financial management and governance.

\section{Implications}

Several conclusions can be drawn from the above discussion whilst bearing in mind that this article barely scratches the surface of a rich body of information. There is much more to be gleaned from the PE, work values and the meaning of work in the current time frame.

The first set of conclusions can collectively be described as the achievement of the purpose of this article, which set out to indicate that the PE functions as a contributory towards meaningful experience by employees whilst performing work roles in the workplace or workspace. This then indicates that PE can serve as a contributory towards meaningful work-life experiences and thus a meaningful workplace:

- It is a valid conclusion to state that the PWE, as an ethical system, is an identifiable and valid construct to which individuals purposefully subscribe, based on cultural influences and choice. This ethic also seems to be intrinsically imbedded in, or aligned with, core work-value types and probably in and with universal individual values pertaining to work.

- The PE has identifiable touch points with other disciplines such as psychology, management and economic sciences, theology, anthropology and sociology.

- The PE as a value system has robustly been indicated to correspond with work-value types and individual (human) core values. All of these values are seated in the individual, thus indicating an intrapersonal congruence of values. This serves as an indication of 'wholeness', thus directing the reasoning towards a perspective on the individual as a holistically integrated human being even within a work setting.

- The PE has its place in the world of work and as such acts as a facilitating force to perform to the best of a person's ability, thereby fulfilling a spiritual-based approach towards work, which best describes involvement in work as a calling or a vocation.

- Individuals who subscribe to the PE are more committed to the organisation, provided management practice creates the psychological and spiritual space for living these values.

- PE represents a certain mental model or approach towards work, which in its own right adds value to the experience of meaningfulness at work.

- Kelvin in Furnham (1984:99) does not foresee a total collapse or disappearance of PE. A transformation however seems inevitable. Closely associated with the $\mathrm{PE}$ is a 'wealth ethic' that is perceived as the basis for 
independence. Sufficient wealth would enable one to be independent of others' support. Work (in whichever format) that produces capital growth is the only way to achieve this objective.

A second set of implications that emanate from the discussion pertain to the work of the church in the world. The following remarks are nothing more than intuitive comments emanating from the study and bearing in mind the above discussion:

- The economic substructure in relation to the work of the church must be noted.

- The output of a capitalist economic system serves as the financial supply side for religion. The church depends on this supply for the execution of her calling. Financial resources (which do not replace voluntary human participation in church activities) are required for growth and expansion. Every act of proclamation by the church in the world, whether a sermon, a pastoral intervention, diaconal support, providing food and clothing, catechism, et cetera can be construed as an economic act. This does not replace the deeper underlying dimension of the calling of the church and her obedience to voice of God.

- The fact that the church is imbedded in a world driven by economic factors and markers implies that the church is required to play an integral role in fostering a work ethic that will contribute towards economic growth and stability, eventually also benefitting her as far as her calling is concerned.

- The inculcation of an ethic that can serve as a driving force to embark on the path of purposeful economic activity is a notable dimension of the moral and ethical education within the church of her members. It is an ethic that is at home in the mental modelling of the believers and can eventually serve as the impetus to counter possible negative mindsets such as defeatism and economic hopelessness In this manner, the church can contribute to the economic wellbeing of South African society at large and serve her own purpose of the proclamation of the gospel.

- It must also be stated that the church has to fulfil her calling towards a society that is hampered by poverty by ensuring fair practice in terms of the management and governance within the domains of macro- and microeconomics. Underlying values and ethics grounded in a religio-spiritual system can counter the current trends in the South African economy which their roots in unabridged greed.

\section{Concluding remarks}

The Protestant (work) ethic is more than a cultural norm that places a positive moral value on doing a good job. It is based on a belief that work has intrinsic value for its own sake (Cherrington 1980; Quinn 1983; Yankelovich \& Immerwahr 1983). It is an imbedded value system of which the traces can be identified or recognised through the analysis of universal human values and work values. Like other cultural norms, a person's adherence to or belief in this particular work ethic is principally influenced by socialisation experiences during childhood and adolescence. A person learns to place a value on dedication and immersion in work behaviour for the benefit of the self and the bigger society, or you refuse this. A child appraises his or her performance in household chores or later in part-time jobs on the perspective of others. As she matures, these attitudes toward work become internalised, and work performance is less dependent on the reactions of others. These attitudes eventually become imbedded as deep-seated values and manifest in behaviour related to meaningful experiences at work thus perceptually transforming the workplace into a meaningful psychological and spiritual space.

The principles and values emanating from PE, translated as the spirit or ethic of responsible capitalism, can indeed function as a contributory to a meaningful workplace. But can we still refer to the construct as 'Protestant ethic'? For some, it will always remain 'Protestant'. For others, the concept 'Protestant' might be offensive, or they might prefer some other expression such as the ethic or spirit of responsible capitalism. Whatever the choice, the underlying principles and values will always remain a work ethic that can contribute to meaningful work experiences and a value system that is aligned with universal individual values pertaining to work and to work-type values. By inference, it contributes towards the establishment and maintenance of a meaningful workplace.

In the work-setting or as value system, PE does not present itself as either opposing or threatening other religiousspiritual value systems. It can be a value system that seeks economic growth and prosperity and which, for furthering the good of society, exist in harmony with other such value systems in the workplace. The possibility exists that a comparison of such belief and value systems (as mentioned earlier) might provide evidence of corresponding value types although with salient differences as was indicated in the comparison between managers subscribing to the 'Protestant ethic' and managers subscribing to a 'Confucian ethic'.

For the current, it is argued that the ethic and value system underlying PE is still valid and remains in its core essence a valuable concept that can enhance, through the living of this core essence, the workplace experiences of employees whilst at the same time contributing towards the betterment of society.

\section{Acknowledgement Competing interest}

The author declares that he has no financial or personal relationship(s) which may have inappropriately influenced them in writing him article.

\section{References}

Balnaves, M. \& Caputi, P., 2001, Introduction to quantitative research methods: An investigative approach, Sage, Thousand Oaks, CA.

Basini, S. \& Buckley, F., 1996-1997, Employee needs and expectations in the Irish voluntary sector, DCUBS Research papers 1996-1997. Monthly Labour review. 
Beit-Hallahmi, B., 1979, 'Personal and social components of the protestant ethic', Journal of Social Psychology 109, 263-267. http://dx.doi.org/10.1080/00224545 1979.9924202

Cherrington, D.J., 1980, The work ethic: Working values and values at work, Amacom, New York. PMCid:371388

Dahrendorf, R., 2010, 'After the crisis: Back to the Protestant ethic?', Max Weber Studies 10(1), 11-21.

Etzrodt, C., 2008, 'Weber's Protestant-ethic thesis, the critics and Adam Smith', Max Weber Studies 8(1), 49-78.

Furnham, A., 1984, 'The protestant work ethic: A review of psychological literature' European Journal of Social Psychology 14, 87-104. http://dx.doi.org/10.1002/ ejsp.2420140108

Furnham, A. \& Koritsas, E., 1990, 'The protestant work ethic and vocational preference', Journal of Organizational Behavior 11, 43-55. http://dx.doi. org/10.1002/ejsp.2420200605

Giorgio, L. \& Marsh, C., 1990, 'The Protestant work ethic as a cultural phenomenon', European Journal of Social Psychology 20(6), 499-517.

Griffin, R.W. \& Bateman, T.S., 1986, 'Job satisfaction and organizational commitment', in C.L. Cooper \& I. Robertson (eds.), International Review of Industrial Psychology, pp. 157-188, Wiley \& Sons, New York, NY.

Hui, C.H., 1992, 'Values and attitudes', in R.I. Westwood (ed.), Organizationa behaviour: Southeast Asian perspectives, pp. 13-60, Longman, Hong Kong.

Jones, W.T., 1975, Kant and the nineteenth century, Harcourt Brace Jovanovich, Inc. New York, NY.

Le Roux, J., 2004, 'Die mag van religieuse idees', HTS Teologiese Studies/Theological Studies 60(3), 743-753 http://dx.doi.org/10.4102/hts.v60i3.611

Lipset, S.M., 1992, 'The work ethic, then and now', Journal of Labor Research 13(1), 45-54. http://dx.doi.org/10.1007/BF02685449

Locke, E.A., 1976, 'The nature and causes of job satisfaction', in M.D. Dunnette \& L.M. Hough (eds.), Handbook of industrial and organizational psychology, pp. 13191328, Consulting Psychologists Press, Palo Alto, CA.

Magdoff, H., 2006, 'The meaning of work: A Marxist perspective', Monthly Review: An Independent Socialist Magazine 58(5), 52-64.

Morse, N.C. \& Weiss, R.S., 1955, 'The function and meaning of work and the job', American Sociological Review 20(2), 191-198. http://dx.doi.org/10.2307/2088325
Newton, I., 1846, 'The Mathematical Principles of Natural Philosophy (1846)', transl. A. Motte, in WikiSource, viewed 11 March 2013, from: http://en.wikisource.org/ wiki/The_Mathematical_Principles_of_Natural_Philosophy_(1846)

Quinn, J.F., 1983, 'The work ethic and retirement', in J. Barbash, R.J. Lampman, S.A. Levitan \& G. Tyler (eds.), The work ethic: A critical analysis, pp. 87-100, Industrial Relations Research Association, Madison, WI.

Rodgers, D.T., 1978, The work ethic in industrial America, 1850-1920, The University of Chicago Press, Chicago, IL. http://dx.doi.org/10.7208/ chicago/9780226723495.001.0001

Rose, M., 1985, Reworking the work ethic: Economic values and socio-cultural politics, Schocken, London.

Ros, M., Schwartz, S.H., \& Surkiss, S., 1999, 'Basic individual values, work values, and the meaning of work', Applied psychology 48(1), 49-71. http://dx.doi. org/10.1111/j.1464-0597.1999.tb00048.x

Steenkamp, P.L., 2012, 'A meaningful workplace: From theory development to applicability', unpublished PhD dissertation, Department of Human Resource Management, University of Pretoria.

Steenkamp, P.L. \& Basson, J.S., 2013, 'A meaningful workplace: Framework, space and context', HTS Teologiese Studies/Theological Studies 69(1), Art. \#1258, 9 pages. http://dx.doi.org/10.4102/hts.v69i.1.1258

Super, D.E., 1982, 'The relative importance of work: Models and measures for meaningful data', The Counseling Psychologist 10(4), 95-103. http://dx.doi. org $/ 10.1177 / 0011000082104018$

Sverko, B., 1999, 'The work importance study: Recent changes of values in Croatia', Applied Psychology: An International Review 48(1), 89-102.

Tilgher, A., 1930, Homo faber: Work through the ages, transl. D.C. Fisher, Harcourt Brace, New York, NY.

Weber, M., 1905a, The Protestant ethic and 'The spirit of capitalism', transl. S. Kalberg, Roxbury Publishing Company, Los Angeles, CA.

Williams, S. \& Sandler, R.L., 1995, 'Work values and attitudes: Protestant and Confucian ethics as predictors of satisfaction and commitment', Research and Practice in Human Resource Management 3(1), 1-13

Yankelovich, D., 1981, New rules: Searching for self-fulfilment in a world turned upside down, Random House, New York, NY.

Yankelovich, D. \& Immerwahr, J., 1983, 'Management and the work ethic', Directors and Boards, Fall, 41-45. 